\title{
DCCs among Sector Indexes and Dynamic Causality between Foreign Exchange and Equity Sector Volatility: Evidence from Egypt
}

\author{
Amira Akl Ahmed ${ }^{1,2}$, Rania Ihab Naguib ${ }^{2}$ \\ ${ }^{1}$ Department of Economics, Faculty of Commerce, Benha University, Egypt \\ ${ }^{2}$ Department of Economics, Faculty of Business, Plymouth University, England \\ Corresponding author: Amira Akl Ahmed, Department of Economics, Faculty of Commerce, Benha University, Egypt.
}

Received: October 4, 2017

doi:10.11114/aef.v5i1.2842
Accepted: November 20, $2017 \quad$ Available online: December 4, 2017

URL: https://doi.org/10.11114/aef.v5i1.2842

\begin{abstract}
The objective of the current paper is to explore the co-movements between domestic equity sectors in the Egyptian Exchange (EGX), using the dynamic conditional correlation (DCC) model, and to examine the time-varying causal links between the exchange rate volatility (EXVOL) and sector volatility (SVOL) using the bootstrap Granger non-causality tests in a bivariate VAR, where conditional volatility series are extracted from $\operatorname{GARCH}(1,1)$ model. We employ weekly data. Results show that all estimated DCCs are positive with a clear heterogeneity between the sector pairs. They do not exhibit stable correlation pattern for a prolong time, implying that DCC estimates change in response to price increment shocks to each sector in the pair. Hence, the assumption of static inter-sectoral correlations between domestic sector indexes is invalid when forming and periodically re-balancing portfolios. The global financial crash and the political instability in early 2011 have significantly increased the level of DCCs for four and ten out of fifteen pairs, respectively. Thus, the recent political turmoil in Egypt has widely affect diversification opportunities in the EGX whereas the global financial crash has not. The volatility transmission between SVOL and EXVOL is subject to structural breaks. The bootstrap rolling window estimations show that the casual relationship between SVOL and EXVOL varies across time. These findings would be of great importance to market participants in their hedging and investment decisions since investors and firms are more concerned with industrial sector exposure estimates.
\end{abstract}

Keywords: exchange rate, sector indexes, dynamic conditional correlation, bootstrap, time-varying causality.

JEL Classification: C32, C51, C58, G11.

\section{Introduction}

By early 1990s, Egypt adopted an Economic Reform and Structural Adjustment Programme with the aim of overcoming some macroeconomic imbalances and enhancing the role of stock market to achieving higher economic growth rates. Egypt has taken considerable actions to enhance the role of its stock market (Ahmed, 2014). Since January 2011, Egypt has witnessed a series of political changes and tensions with significant influence on capital and foreign currency markets. Political instability included the January revolution in 2011, the presidential election in 2012, the outset of the president in June 2013, another presidential election in 2014, and the wild clashes between supporters of the outset president and the police. In the two consecutive trading days following $25^{\text {th }}$ of January 2011, panic selling hitting the stock market resulted in a sharp decline of share values by nearly US $\$ 12$ billion (corresponding to $12 \%$ market capitalization). Thus, the market authorities suspended trading for around eight weeks. Over the period extending from January 2011 to October 2015, the market capitalisation decreased by 18\%, the Egyptian pound fell sharply by $34.3 \%$ against the US dollar, and net foreign reserves shrank by 52\% (Ahmed, 2016, 2017). In the beginning of 2007, the Egyptian Exchange (EGX) constructed for the first time 12 equity sector indexes to track the movements of equity prices' The objective of this study is to examine co-movements between domestic equity sectors in the EGX, using the dynamic conditional correlation (DCC) model of Engle and Sheppard (2001) and Engle (2002), and to explore the time-varying causal relation between the exchange rate volatility (EXVOL) and sector volatility (SVOL) using the bootstrap Granger non-causality tests recommended by Balcilar, Ozdemir, and Arslanturk (2010) and Su, Yu, Chang, and $\mathrm{Li}$ (2016) because such relationship is subject to structural shifts during financial crises and recessions. According to the flow-oriented approach, causality runs from foreign exchamge (EX) market to equity market (Dornbusch \& Fisher, 1980) whereas it runs in the opposite direction according to the stock-oriented approach (Branson,1983; Frankel, 
1983). The increasing correlations between national stock markets overtime are likely to erode benefits from international diversification (Goetzmann, Li \& Rouwenhorst, 2005; Hatemi-J \& Roca, 2006; Mollah, Zafirov, \& Quoreshi, 2014). Investors have higher tendency to allocate more capital in domestic financial assets than in their foreign counterparts (Fidora, Fratzcher, \& Thimann, 2007; Baele, Pungulescu, \& Ter Horst, 2007). Fidora et al., (2007) found empirical support that the real exchange rate volatility is an important explanation for the cross-country differences in bilateral home biases in bonds and in equities, with real exchange rate volatility explaining about $20 \%$ of the cross-country variation in equity and bond home biases. This is because exchange rate volatility induces a bias towards local financial assets since it puts additional risk on holding foreign securities from a domestic (currency) investors' perspective. Investing in sector-index offers investors instant diversification benefit besides reduction in trading and functional costs of managing an index portfolio (Ngene \& Gordon, 2015). The importance of industrial (sector) effects relative to country effects has been increasing in explaining variation of international portfolio returns (Ferreira \& Ferreira 2006; Phylaktis \& Xia, 2006). Hence, there would be periods of increased co-movements between assets held domestically across different sectors in investors' portfolios (Katzke, 2013).

To avoid problems associated with daily data (e.g. non-synchronous trading, bid-ask spread and non-trading associated with daily prices), we employ weekly data of the most actively traded sectors. The trade-weighted exchange rate (calculated by J.P. Morgan) is used to better measuring the competitiveness of the economy (Kanas, 2000). We question the following: Do information flows across sectors exhibit heterogeneous patterns of the estimated DCCs? Do the global financial crash and political instability cause structural breaks in the estimated DCCs? Do causal links between the EXVOL and SVOL exist? If yes, is it stable or time-varying? We hypothesize that: (1) the time-varying correlations between sector volatilities exhibit heterogeneous patterns (2) there is time-varying bi-direction causality between EXVOL and SVOL. The two-step DCC-multivarte GARCH (DCC-MGARCH) model enables us to estimate SVOL in the first step. There is an increasing need to study volatility at disaggregated levels [i.e. sector level]. Ewing, Forbes, \& Payne (2003) indicated that financial market participants are concerned not only with how individual equity perform, but also in how sector indices perform. According to the best of our knowledge, this is the first study to examine volatility transmission between sector volatilities for the EGX. Modern portfolio theory stresses upon the importance of correlations in the portfolio selection process. Investors must be aware that correlations between domestic sectors are dynamic and can change sharply given certain trigger events. Studying the interlinks between equity and EX markets is of crucial importance for regulators and investors. Examining the interdependence between these financial markets would help regulators trigger preventive action before the spread of a crisis. Investors are concerned with volatility spillover between the stock and EX markets because variation in equity variance affect optimal investment strategy and diversification. Investors and fund managers would benefit from exploring these interlinks in managing and hedging the risk proficiently given that foreign currency is widely being included as an asset in investment funds' portfolios. More importantly, studying these interlinks at the sector level would be of great use to market participants in their hedging and investment decisions because investors and firms are more concerned with industrial sector exposure estimates (Dimitrova, 2005; Fu, Holmes, \& Daniel, 2011; Kumar, 2013).

Results reveal that DCCs amongst employed local sectors show significant variations over time and that they are positive for all sector pairs. There is a clear heterogeneity in the DCCs between the sector pairs. Sector pairs do not exhibit stable correlation pattern for a prolong period, implying that DCC estimates change in response to price increment shocks to each sector in the pair. These conclusions conform to those of Katzke (2013) and Ngene and Gordon (2015). Our results show that DCCs significantly increased for four (ten) out of fifteen DCC pairs during the global financial crash (political instability in Egypt accompanying the $25^{\text {th }}$ of January revolution). These results are consistent with those of Katzke (2013) who did not find any clear consistent increase or decrease in DCCs for South African domestic sectors during the global financial crisis. However, Tamakoshi and Hamori (2016) found a sharp increase in the DCCs for all UK financial sector pairs after the bankruptcy of Lehman Brothers. The parameter stability tests reveal the presence of structural shifts in the relationship between EXVOL and SVOL, confirming empirical evidence that the relationship between share volatility and macroeconomic volatility is subject to structural shifts during financial crises and recessions (Stock \& Watson, 2002; Beltratti \& Morana, 2006). Hence, inferences made using the full-sample results are invalid. Results obtained from the bootstrap rolling window procedure confirmed that the casual relationship between the EXVOL and SVOL varies across time. Results are consistent with findings of Chinzara (2011) who documented bidirectional volatility transmission between the EXVOL and SVOL in South Africa.

The rest of the paper is structured as follows. Section 2 provides brief literature review. Section 3 introduces the econometric methodology whereas section 4 presents data and empirical results. Finally, section 5 concludes.

\section{Brief Literature Review}

Volatility transmission between financial variables have been investigated using MGARCH models (e.g. Hassan \& Malik, 2007; Katzke, 2013). Hassan and Malik (2007) found significant transmission of shocks and volatility among 
employed US sectors. Tamakoshi and Hamori (2014) detected significant causality-in-variance running from the US financial services sector index to the banking sector index during January 2004 to December 2011. Katzke (2013) and Ngene and Gordon (2015) documented heterogeneous DCCs in pairs of sector returns volatility. In addition, Katzke (2013) did not find any clear consistent increase or decrease in co-movements of volatility of South African domestic sectors during the global financial crisis. In contrast, Tamakoshi and Hamori (2016) found a sharp increase in the DCCs for all UK financial sector pairs after the bankruptcy of Lehman Brothers, and decreases for two pairs (banking-life insurance and life insurance-other financial) after the summit of the European debt crisis in September 2011, implying the emergence of diversification opportunities. Kanas (2000) documented volatility spillovers from stock market to EX market for all six industrial countries except Germany whereas no evidence was found of volatility spillovers in the opposite direction for any country. Furthermore, Caporale, Hunter, \& Ali (2014) found causality in variance from stock returns to EX changes for US during 2007-2010 and in the opposite direction for the Euro area and Japan, while an evidence of bidirectional feedback was documented for Switzerland and Canada during the same period. Volatility spillover research carried on emerging stock and foreign exchange markets (e.g. Choudhry (2004); Morales (2008); and references cited in Kumar (2013)) gave similar results to those studies done on developed markets. MGARCH models have been employed to explore volatility spillovers between EX and equity markets (Caporale et al., 2014; Choudhry, 2004; Kanas, 2000; Kumar, 2013; Morales, 2008). Volatility transmission between financial markets could be examined using the two-step GARCH-VAR framework, whereby conditional volatility of financial variables is extracted from univariate GARCH models and, then, VAR model is used to test for causality between their conditional variances [e.g. Kumari \& Mahakud (2015) and Morelli (2002) who found unidirectional causality from EX to stock market volatility in the UK and bidirectional causality for India, respectively]. Using sector index is recommended since sector-specific responses to macroeconomic volatility may not be identical due to underlying differences in market and industrial characteristics (Chinzara, 2011; Ewing et al., 2003; Fu et al., 2011; Jayasinghe \& Tsui, 2008; Koutmos \& Knif, 2003; Koutmos \& Martin, 2003). Chinzara (2011) found bidirectional causality between EXVOL and SVOL of retail, and mining sectors in South Africa. Empirical evidence supports that the relationship between share volatility and macroeconomic volatility is subject to structural shifts during financial crises and recessions (Stock \& Watson, 2002; Beltratti \& Morana (2006); Chinzara (2011)].

\section{Methodology}

\subsection{DCC - GARCH}

In the first step of estimating the DCC- MGARCH model of Engle and Sheppard (2001) and Engle (2002), univariate GARCH $(1,1)$ model is fitted for returns of each sector index. Then, the standardized residuals resulting from the first step are employed to estimate a simple GARCH-like time varying correlation. This parameterization preserves the simple interpretation of univariate GARCH models. This methodology could be expressed as follows.

$$
\begin{aligned}
& r_{t}=\varphi_{0}+\varphi_{1} r_{t-1}+\varepsilon_{t}, \quad \varepsilon_{t} \mid \Omega_{t-1} \sim N\left(0, H_{t}\right) \\
& h_{i, t}=\omega+\alpha_{1} \varepsilon_{i, t-1}^{2}+\beta_{1} h_{i, t-1}, \\
& \omega>0 ; \alpha_{1}>0 ; \beta_{1}>0 ; \alpha_{1}+\beta_{1}<1 \\
& \varepsilon_{t}=H_{t}^{1 / 2} u_{t}, \quad u_{t} \sim N(0, I) \\
& H_{t}=D_{t} R_{t} D_{t}
\end{aligned}
$$

where $r_{t}$ is the $k \times 1$ vector of asset returns, including each first difference of employed sector indexes with conditional mean assumed to follow an $\operatorname{AR}(1)$ model. $\varepsilon_{t}$ is a $k \times 1$ vector of asset returns innovation with zero mean conditional on information available at time $\mathrm{t}-1 . \Omega_{t-1}$ is the information set at time $\mathrm{t}-1 . u_{t}$ is $k \times 1$ vector of the standardised residuals. $h_{i, t}$ is the conditional variance which is assumed to follow a $\operatorname{GARCH}(1,1) . H_{t}$ is $k \times k$ matrix of conditional variance-covariance. $D_{t}$ is the diagonal matrix of the conditional standard deviation, and $R_{t}$ is the time-varying correlation matrix. We represent the DCC model as:

$$
Q_{t}=\left(1-\theta_{1}-\theta_{2}\right) \bar{Q}+\theta_{1} u_{t-1} u_{t-1}^{\prime}+\theta_{2} Q_{t-1}
$$

Where $\bar{Q}$ is the unconditional covariance matrix of $u_{t}$. Hence, non-negative scalar variables, $\theta_{1}$, and $\theta_{2}$, must satisfy the condition $\theta_{1}+\theta_{2}<1$ to ensure mean reverting property. The matrix containing time-varying conditional correlations is derived by Equation (6). Where $Q_{t}^{*}$ is a diagonal matrix including the square root of the diagonal entries of $Q_{t}$. The typical element of $R_{t}$ is of the form $\rho_{i j t}=\frac{q_{i j t}}{\sqrt{q_{i i} q_{i i}}}$. 
To test for structural shifts in the level of the pairwise DCCs, we follow Mollah et al. (2014) through employing model illustrated in Equation (7). If dynamics in the second moment of the DCCs are detected, we follow Muñoz, Marquez, \& Sánchez (2011) by applying the methodology, illustrated by Equations (7) and (8).

$$
\begin{gathered}
R_{t} \equiv Q_{t}^{*-1} Q_{t} Q_{t}^{*-1} \\
\rho_{\mathrm{ij}, \mathrm{t}}=\rho_{0}+\rho_{\mathrm{ij \textrm {j } t}-1}+\gamma_{k} \text { Crisis }_{k, t}+e_{i j, t} \\
h_{i j, t}=\omega+\alpha_{1} \varepsilon_{i j, t-1}^{2}+\beta_{1} h_{i j, t-1}+\delta_{k} \text { Crisis }_{k, t}
\end{gathered}
$$

Crisis $_{k}$ for $\mathrm{k}=1,2$ is a dummy variable for the global financial crash (1/9/2008 to 31/12/2009) and the political instability in 2011 (26/1/2011 to 30/3/2011), respectively. Following Mollah et al. (2014), we specify the start date of the recent global financial crash as the beginning of September 2008. Crisis variables take the value of one during the crisis and zero otherwise. A significant estimated coefficient for the dummy variable would be interpreted as a structural shift in the mean and/or variance of the pairwise DCCs

\subsection{Bootstrap Granger Causality Test}

The residual bootstrap (RB) based modified-LR statistics is employed to investigate the presence of causality between SVOL and EXVOL in the EGX. The robustness of the RB based modified-LR statistics over standard asymptotic Granger non-causality tests, irrespective of integration properties sample sizes, integration orders, and error term processes (homoscedastic or ARCH), have been documented (see for example, Balcilar et al., 2010). Consider the following bivariate $\operatorname{VAR}(\mathrm{p})$ process:

$$
\mathrm{y}_{\mathrm{t}}=\alpha_{0}+\alpha_{1} \mathrm{y}_{\mathrm{t}-1}+\cdots+\alpha_{\mathrm{p}} \mathrm{y}_{\mathrm{t}-\mathrm{p}}+\epsilon_{\mathrm{t}} \quad \mathrm{t}=1,2, \ldots, \mathrm{T}
$$

where $\epsilon_{t}=\left(\epsilon_{1 t}, \epsilon_{2 t}\right)^{\prime}$ is a zero mean IID process with non-singular covariance matrix $\Sigma$ and $p$ is the order of the process which is determined according to the Akaike Information Criterion (AIC)' If $\mathrm{y}_{\mathrm{t}}=\left(y_{E X V O L}, y_{S V O L}\right)^{\prime}$ is divided into sub-vectors, $y_{E X V O L}$ and $y_{S V O L}$, Equation (9) can be re-written in the following form.

$$
\left[\begin{array}{l}
y_{E X V O, t} \\
y_{S V O L, t}
\end{array}\right]=\left[\begin{array}{l}
\alpha_{10} \\
\alpha_{20}
\end{array}\right]+\left[\begin{array}{ll}
\alpha_{11}(L) & \alpha_{12}(L) \\
\alpha_{21}(L) & \alpha_{22}(L)
\end{array}\right]\left[\begin{array}{l}
y_{F X V O, t} \\
y_{S V O L, t}
\end{array}\right]+\left[\begin{array}{l}
\epsilon_{1 t} \\
\epsilon_{2 t}
\end{array}\right]
$$

where $y_{E X V O, t}$ and $y_{S V O L, t}$ represent EXVOL and SVOL, respectively. $\alpha_{i j}(L)=\sum_{k=}^{p} \alpha_{i j, k} L^{k}, i, j=1,2$ and $\mathrm{L}$ is the lag operator defined as $L^{k} X_{t}=X_{t-k}$. The null hypothesis that SVOL does not Granger-cause EXVOL is tested by imposing the restrictions $\alpha_{12, i}=0$ for $i=1,2, \ldots p$ whereas the null hypothesis that EXVOL does not Granger-cause SVOL is tested by imposing the restriction $\alpha_{21, i}=0$ for $i=1,2, \ldots p$. In the presence of structural changes or regime shifts, inferences made about the full-sample causality link are misleading (Balcilar et al., 2010; Balcilar \& Ozdemir, 2013; Su et al., 2016). Thus, we test for parameter stability using the Sup-LR, Mean-LR and Exp- LR tests, proposed by Andrews (1993) and Andrews and Ploberger (1994), based on the sequence of Lagrange multiplier statistics. If parameter instabilities are detected, then the rolling window procedure, that uses a fixed-length moving window, will be applied through dropping the first observation in the window and moving forward and adding a new observation. For every sub-sample, the RB-based modified-LR test can be performed using a large number of repetitions, say 2000, to ensure accuracy of the results. The time-varying causality between the EXVOL and SVOL can be observed by computing the bootstrap $p$-values of these estimations (Balcilar et al., 2010; Su et al., 2016). The window size is set to be 150 and 200 observations, corresponding to around 3 and 4 years of weekly data, respectively. An important advantage of the bootstrap method is its ability to effectively increase the accuracy of estimates by increasing the number of replications when the window size is small (Su et al., 2016).

\section{Data and Empirical Results}

\subsection{Data}

Wednesday closing prices of the most active sector indexes, accounting for around $70 \%$ of total market capitalization during 2007-2015, are employed. These sectors are Banks (BAN), Chemicals (CHM), Construction and Materials (COM), Financial Services excluding Banks (FNS), Industrial Goods and Services and Automobiles (ING), and Telecommunication (TEL). The study period extends from $3^{\text {rd }}$ of January 2007 (the day of inception) to $3^{\text {rd }}$ of February 2016. We collect sector data from the Egyptian Exchange website. The weekly trade-weighted index of exchange rate is obtained from Bloomberg. In total, 463 observations are included in this analysis. Returns are defined as the difference of the logarithm of the price index scaled by 100 .

\subsection{Preliminary Analysis of the Data ${ }^{l}$}

All series are likely not to be drawn from normal distribution according to skewness kurtosis, and Jarque-Bera test statistic. All financial series exhibit substantial significant second moment dependence according to the Ljung-Box Q statistic for squared return. Moreover, the significance of Ljung-Box Q statistic for return series of some indexes (e.g. 
FNS and TEL indexes) indicates that these series exhibit weak first moment dependence. ADF test of Dickey and Fuller (1981) indicates that all return series are stationary. All unconditional correlation coefficients are positive and significantly different from zero. However, such static estimates of correlation between returns are likely to be misleading given the dependence in the second moments of individual return series.

\subsection{Results of Univariate GARCH Models}

Table 1 presents the parameter estimates of AR-GARCH(1,1) model, their corresponding $p$-values, $\log$-likelihood, and diagnostic tests. Diagnostic tests include the Box-Pierce portmanteau statistic for the first ten autocorrelations of standardised residuals and squared standardised residuals (i.e. $L B \mathrm{Q}_{(10)}$ and $\mathrm{LB}^{2} \mathrm{Q}_{(10)}$, respectively), and the $\mathrm{LM} \mathrm{ARCH}_{(10)}$ test procedure of Engle (1982) which tests the joint significance of the regression coefficients of the squared residuals on their own past values up to lag 10. The test statistic is distributed as $\chi^{2}(p)$ where $\mathrm{p}$ is the number of lags. Estimates of AR-GARCH $(1,1)$ model are obtained using the quasi-maximum likelihood estimator of Bollerslev and Woolbridge (1992). For BAN and CHM returns and EX series, a mean equation that includes only a constant is found adequately to describe their first moments, given that standardised residuals up to lag 10 are found free from serial correlation. The constant term in the mean equation is found statistically insignificant for all series except that of BAN. The mean equation that includes an intercept and an AR(1) term is found adequate for TEL's returns whereas that with an intercept and an AR(2) is found adequate to fit returns of COM, FNS, and ING sectors, because standardised residuals up to lag 10 are free from autocorrelation. The $\operatorname{GARCH}(1,1)$ model is found adequate to fit the second moment of all employed series since squared standardised residuals are found free from autocorrelation and ARCH effects up to 10 lags. Moreover, the estimated models are found to be stable since the joint Nyblom-Hansen test statistic joint $\mathrm{L}_{\mathrm{C}}$, is found less than critical one at $5 \%$ for all return series. The joint $\mathrm{L}_{\mathrm{C}}$ statistic tests the null that the entire vector of parameters is stable against the alternative that the entire vector may be unstable (i.e. following a martingale process). As argued by Nyblom (1989), this encompasses the case of one or more structural breaks. The test statistic has an asymptotic distribution which depends only on the number of estimated parameters. Nyblom (1989) and Hansen (1990) tabulated this distribution. The test statistic is robust for heteroscedasticity.

Table 1. Estimates results of univariate GARCH(1,1) model

\begin{tabular}{|c|c|c|c|c|c|c|c|}
\hline \multirow[t]{3}{*}{ Coefficients } & \multicolumn{6}{|c|}{ Sector } & \multirow[b]{2}{*}{ EX } \\
\hline & BAN & CHM & COM & FNS & ING & TEL & \\
\hline & \multicolumn{7}{|c|}{ Mean equation } \\
\hline $\begin{array}{c}\hat{\mu}_{0} \\
\text { p-value }\end{array}$ & $\begin{array}{c}0.388 * * \\
{[0.02]} \\
\end{array}$ & $\begin{array}{l}0.023 \\
{[0.88]} \\
\end{array}$ & $\begin{array}{l}0.065 \\
{[0.71]}\end{array}$ & $\begin{array}{l}-0.107 \\
{[0.62]} \\
\end{array}$ & $\begin{array}{l}0.148 \\
{[0.39]} \\
\end{array}$ & $\begin{array}{l}-0.316 \\
{[0.24]} \\
\end{array}$ & $\begin{array}{l}-0.008 \\
{[0.79]} \\
\end{array}$ \\
\hline $\begin{array}{c}\hat{\mu}_{1} \\
\text { p-value }\end{array}$ & - & - & - & - & - & $\begin{array}{c}0.116^{* * *} \\
{[0.02]}\end{array}$ & - \\
\hline $\begin{array}{c}\hat{\mu}_{2} \\
\text { p-value } \\
\end{array}$ & - & - & $\begin{array}{c}0.094 * * \\
{[0.05]} \\
\end{array}$ & $\begin{array}{c}0.124^{*} \\
{[0.01]} \\
\end{array}$ & $\begin{array}{l}0.163^{*} \\
{[0.00]} \\
\end{array}$ & - & - \\
\hline Coefficients & \multicolumn{7}{|c|}{ Variance equation } \\
\hline $\begin{array}{c}\widehat{\omega} \\
\mathrm{p} \text {-value }\end{array}$ & $\begin{array}{l}1.23 * * \\
{[0.03]}\end{array}$ & $\begin{array}{l}3.82 * * \\
{[0.02]}\end{array}$ & $\begin{array}{l}1.11 * * \\
{[0.04]}\end{array}$ & $\begin{array}{l}5.37 * * \\
{[0.05]}\end{array}$ & $\begin{array}{c}2.24 \\
{[0.09]}\end{array}$ & $\begin{array}{l}11.22 \\
{[0.09]}\end{array}$ & $\begin{array}{l}0.030 * * \\
{[0.050]}\end{array}$ \\
\hline $\begin{array}{c}\widehat{\alpha}_{1} \\
\text { p-value }\end{array}$ & $\begin{array}{c}0.079^{* * *} \\
{[0.05]}\end{array}$ & $\begin{array}{l}0.196^{*} \\
{[0.00]}\end{array}$ & $\begin{array}{c}0.114 * * * \\
{[0.03]}\end{array}$ & $\begin{array}{c}0.123^{* *} \\
{[0.04]}\end{array}$ & $\begin{array}{c}0.129^{* *} \\
{[0.04]}\end{array}$ & $\begin{array}{c}0.093 * * \\
{[0.05]} \\
\end{array}$ & $\begin{array}{l}0.162^{*} \\
{[0.00]}\end{array}$ \\
\hline $\begin{array}{c}\hat{\beta}_{1} \\
\text { p-value }\end{array}$ & $\begin{array}{l}0.857^{*} \\
{[0.00]}\end{array}$ & $\begin{array}{l}0.592^{*} \\
{[0.00]}\end{array}$ & $\begin{array}{c}0.839^{*} \\
{[0.00]}\end{array}$ & $\begin{array}{c}0.678^{*} \\
{[0.00]}\end{array}$ & $\begin{array}{c}0.783^{*} \\
{[0.00]}\end{array}$ & $\begin{array}{c}0.623^{*} \\
{[0.01]}\end{array}$ & $\begin{array}{l}0.813^{*} \\
{[0.00]}\end{array}$ \\
\hline \multicolumn{8}{|c|}{ Model diagnostics } \\
\hline$\widehat{\omega}_{1}+\ddot{\beta}_{1}$ & 0.936 & 0.788 & 0.953 & 0.801 & 0.912 & 0.716 & 0.975 \\
\hline Log-Likelihood & -1319.4 & -1295 & -1330.6 & -1402.3 & -1357.17 & -1493.5 & -554.26 \\
\hline LB Q $(10)$ & $\begin{array}{l}11.62 \\
{[0.31]} \\
\end{array}$ & $\begin{array}{c}7.48 \\
{[0.76]}\end{array}$ & $\begin{array}{c}9.99 \\
{[0.18]} \\
\end{array}$ & $\begin{array}{c}5.92 \\
{[0.82]} \\
\end{array}$ & $\begin{array}{c}12.77 \\
{[0.23]} \\
\end{array}$ & $\begin{array}{c}5.81 \\
{[0.83]} \\
\end{array}$ & $\begin{array}{l}8.13 \\
{[0.61]} \\
\end{array}$ \\
\hline $\mathrm{LB}^{2} \mathrm{Q}_{(10)}$ & $\begin{array}{c}5.24 \\
{[0.87]}\end{array}$ & $\begin{array}{l}12.75 \\
{[0.23]}\end{array}$ & $\begin{array}{l}10.32 \\
{[0.41]}\end{array}$ & $\begin{array}{c}6.22 \\
{[0.79]}\end{array}$ & $\begin{array}{c}3.25 \\
{[0.97]}\end{array}$ & $\begin{array}{l}11.74 \\
{[0.30]}\end{array}$ & $\begin{array}{l}1.68 \\
{[0.99]}\end{array}$ \\
\hline LM-ARCH $_{(10)}$ & $\begin{array}{c}5.69 \\
{[0.84]} \\
\end{array}$ & $\begin{array}{r}11.95 \\
{[0.28]} \\
\end{array}$ & $\begin{array}{c}9.11 \\
{[0.52]}\end{array}$ & $\begin{array}{c}6.48 \\
{[0.77]} \\
\end{array}$ & $\begin{array}{c}3.25 \\
{[0.97]} \\
\end{array}$ & $\begin{array}{l}10.76 \\
{[0.37]} \\
\end{array}$ & $\begin{array}{l}1.79 \\
{[0.99]}\end{array}$ \\
\hline $\begin{array}{l}\text { Joint } L_{C} \\
\text { Critical value }\end{array}$ & $\begin{array}{l}0.480 \\
{[1.24]} \\
\end{array}$ & $\begin{array}{c}1.22 \\
{[1.24]}\end{array}$ & $\begin{array}{c}1.35 \\
{[1.47]}\end{array}$ & $\begin{array}{l}1.280 \\
{[1.47]} \\
\end{array}$ & $\begin{array}{c}1.06 \\
{[1.47]} \\
\end{array}$ & $\begin{array}{c}1.30 \\
{[1.47]} \\
\end{array}$ & $\begin{array}{l}0.851 \\
{[1.24]} \\
\end{array}$ \\
\hline Half-life period & 10.48 & 2.91 & 14.39 & 3.12 & 7.52 & 2.07 & 27.3 \\
\hline
\end{tabular}

Source: Authors' calculations

All coefficients in variance equations are found to be significantly different from zero at the conventional levels of significance. All ARCH coefficients are lower than their GARCH counterparts implying that the last week shock tends to have less influence on future volatility compared to old shock. The sum of the estimated ARCH and GARCH coefficients $\widehat{\alpha}_{1}+\widehat{\beta}_{1}$, shown in Table 1, is less than one for all series implying that models are covariance stationary 
and that volatility is mean reverting. The volatility persistence measured by the sum of the estimated ARCH and GARCH coefficients varies across sectors. The persistence is higher than 0.9 for Banks, Construction and Materials, and Financial Services excluding Banks and for the EX series. The high level of persistence in volatility can be described by the half-life period, which shows the number of periods a shock takes to reduce to half its original size. It is calculated as $\left[\log (0.5) / \log \left(\hat{\alpha}_{1}+\hat{\beta}_{1}\right)\right]$. The half-life of volatility implied by estimated $\operatorname{GARCH}(1,1)$ models for employed sectors are around 11, 3, 15, 3, 8 and 2 weeks for BAN, CHM, COM, FNS, ING, and TEL sectors. Thus, a shock to returns of the Construction and Materials sector, with the highest volatility persistence, takes around 15 weeks to move halfway back towards its unconditional mean following a deviation from it. On the other hand, the Telecommunications sector with lowest volatility persistence, takes around 2 weeks for a shock of price increments to shrink half its original size. Thus, there is an evidence of significant heterogeneity in persistence of volatility. The statistical significance of all the variance coefficients indicates presence of conditional heteroscedasticity in returns of all employed sectors greatly undermines the accuracy of static unconditional correlations of returns across sectors. Thus, an important step is then to use the standardized residuals obtained from the estimated univariate $\operatorname{GARCH}(1,1)$ models above to estimate the time-varying DCC series by maximizing the aforementioned log-likelihood functions.

\subsection{Dynamic Conditional Correlation Patterns among Sectors}

Table 2. DCC $(1,1)$ estimates

\begin{tabular}{|c|c|c|c|c|c|c|c|c|c|c|c|c|}
\hline \multirow[t]{2}{*}{ Sector } & \multicolumn{2}{|l|}{ BAN } & \multicolumn{2}{|l|}{ CHM } & \multicolumn{2}{|l|}{$\mathrm{COM}$} & \multicolumn{2}{|l|}{ FNS } & \multicolumn{2}{|l|}{ ING } & \multicolumn{2}{|c|}{ TEL } \\
\hline & $\theta_{1}$ & $\theta_{2}$ & $\theta_{1}$ & $\theta_{2}$ & $\begin{array}{l}\theta_{1} \\
\end{array}$ & $\theta_{2}$ & $\theta_{1}$ & $\theta_{2}$ & $\theta_{1}$ & $\theta_{2}$ & $\theta_{1}$ & $\theta_{2}$ \\
\hline $\mathrm{CHM}$ & $\begin{array}{l}0.061 \\
{[0.08]}\end{array}$ & $\begin{array}{l}0.755 \\
{[0.00]}\end{array}$ & & & & & & & & & & \\
\hline \multirow{2}{*}{$\begin{array}{l}\text { Mean of } \rho_{i j, t} \\
\text { Std. of } \rho_{i j, t}\end{array}$} & $* * *$ & & & & & & & & & & & \\
\hline & \multicolumn{2}{|l|}{$\begin{array}{l}0.562 \\
0.069\end{array}$} & & & & & & & & & & \\
\hline $\mathrm{COM}$ & $\begin{array}{l}0.028 \\
{[0.05]} \\
* *\end{array}$ & $\begin{array}{l}0.927 \\
{[0.00]} \\
*\end{array}$ & $\begin{array}{l}0.053 \\
{[0.00]} \\
*\end{array}$ & $\begin{array}{l}0.895 \\
{[0.00]} \\
*\end{array}$ & & & & & & & & \\
\hline $\begin{array}{l}\text { Mean of } \rho_{i j, t} \\
\text { Std. of } \rho_{i j, t}\end{array}$ & \multicolumn{2}{|l|}{$\begin{array}{l}0.612 \\
0.071\end{array}$} & \multicolumn{2}{|c|}{$\begin{array}{l}0.558 \\
0.115 \\
\end{array}$} & & & & & & & & \\
\hline \multirow{2}{*}{$\begin{array}{l}\text { FNS } \\
\text { Mean of } \rho_{i j, t} \\
\text { Std. of } \rho_{i j, t}\end{array}$} & $\begin{array}{l}0.079 \\
{[0.07]} \\
* * *\end{array}$ & $\begin{array}{l}0.565 \\
{[0.07]} \\
* * *\end{array}$ & $\begin{array}{l}0.053 \\
{[0.11]}\end{array}$ & $\begin{array}{l}0.780 \\
{[0.00]} \\
*\end{array}$ & $\begin{array}{l}0.017 \\
{[0.11]}\end{array}$ & $\begin{array}{l}0.940 \\
{[0.00]} \\
*\end{array}$ & & & & & & \\
\hline & \multicolumn{2}{|l|}{$\begin{array}{l}0.710 \\
0.053\end{array}$} & \multicolumn{2}{|c|}{$\begin{array}{l}0.685 \\
0.056\end{array}$} & \multicolumn{2}{|l|}{$\begin{array}{l}0.718 \\
0.037\end{array}$} & & & & & & \\
\hline ING & $\begin{array}{l}0.053 \\
{[0.02]} \\
* *\end{array}$ & $\begin{array}{l}0.864 \\
{[0.00]} \\
*\end{array}$ & $\begin{array}{l}0.095 \\
{[0.05]} \\
* *\end{array}$ & $\begin{array}{l}0.567 \\
{[0.04]} \\
* *\end{array}$ & $\begin{array}{l}0.025 \\
{[0.04]} \\
* *\end{array}$ & $\begin{array}{l}0.919 \\
{[0.00]} \\
*\end{array}$ & $\begin{array}{l}0.095 \\
{[0.05]} \\
* *\end{array}$ & $\begin{array}{l}0.567 \\
{[0.04]} \\
* *\end{array}$ & & & & \\
\hline $\begin{array}{l}\text { Mean of } \rho_{i j, t} \\
\text { Std. of } \rho_{i j, t}\end{array}$ & \multicolumn{2}{|l|}{$\begin{array}{l}0.707 \\
0.068 \\
\end{array}$} & \multicolumn{2}{|c|}{$\begin{array}{l}0.778 \\
0.095 \\
\end{array}$} & \multicolumn{2}{|l|}{$\begin{array}{l}0.678 \\
0.055 \\
\end{array}$} & \multicolumn{2}{|l|}{$\begin{array}{l}0.778 \\
0.051 \\
\end{array}$} & & & & \\
\hline TEL & $\begin{array}{l}0.123 \\
{[0.03]} \\
* *\end{array}$ & $\begin{array}{l}0.225 \\
{[0.52]}\end{array}$ & $\begin{array}{l}0.051 \\
{[0.02]} \\
* *\end{array}$ & $\begin{array}{l}0.839 \\
{[0.00]} \\
*\end{array}$ & $\begin{array}{l}0.163 \\
{[0.00]} \\
*\end{array}$ & $\begin{array}{l}0.532 \\
{[0.00]} \\
*\end{array}$ & $\begin{array}{l}0.161 \\
{[0.00]} \\
*\end{array}$ & $\begin{array}{l}0.544 \\
{[0.00]} \\
*\end{array}$ & $\begin{array}{l}0.108 \\
{[0.00]} \\
*\end{array}$ & $\begin{array}{l}0.533 \\
{[0.00]} \\
*\end{array}$ & & \\
\hline $\begin{array}{l}\text { Mean of } \rho_{i j, t} \\
\text { Std. of } \rho_{i j, t}\end{array}$ & \multicolumn{2}{|l|}{$\begin{array}{l}0.610 \\
0.069 \\
\end{array}$} & \multicolumn{2}{|c|}{$\begin{array}{l}0.671 \\
0.111 \\
\end{array}$} & \multicolumn{2}{|l|}{$\begin{array}{l}0.588 \\
0.115 \\
\end{array}$} & \multicolumn{2}{|l|}{$\begin{array}{l}0.775 \\
0.083 \\
\end{array}$} & \multicolumn{2}{|l|}{$\begin{array}{l}0.707 \\
0.060\end{array}$} & & \\
\hline
\end{tabular}

$*, * *, * * *$ indicate statistical significance at $1 \%, 5 \%$, and $10 \%$ levels, respectively.

\section{Source: authors' calculations}

Table 2 summarize the estimates of $\theta_{1}, \theta_{2}$, the mean and standard deviation of the DCC coefficient $\left(\rho_{i j, t}\right)$. The necessary condition of stability, $\theta_{1}+\theta_{2}<1$, has been met for all sector pairs. $\theta_{1}$ is significant at conventional levels of significance for all sector pairs except for FNS-CHM and FNS-COM pairs. The magnitude of $\theta_{1}$ is generally low, ranging from zero (insignificant $\theta_{1}$ ) and 0.163 . Thus, short-run co-movements do not affect co-movement between Financial Services-excluding banks sector and Chemical and Construction and Material sectors. Moreover, $\theta_{2}$ is significant at conventional levels of significance except for TEL-BAN pair. Some sector pairs exhibit slow decay in correlations (or lack of it) as reflected in the high and significant $\theta_{2}$ (persistence) parameter. $\theta_{2}$ is found greater than 0.8 in six sector pairs [BAN-COM, CHM-COM, COM-FNS, BAN-ING, COM-ING, and CHM-TEL] out of fifteen. In such cases, a shock to sector returns is likely to influence expected dynamic correlation over many periods in future. Hence, these findings suggest that all DCCs show significant variations over time. This suggests that the DCC model is adequate at measuring time-varying conditional correlations, and that it displays mean reversion along a constant level. It is worth noting that the mean of DCC estimates, shown in Table 2 along with its standard deviation, differs significantly from the unconditional (static) correlations for some sector pairs. For example, the mean DCC estimates of CHM-COM, BAN-CHM and CHM-ING pairs are 0.558, 0.562, and 0.778 whereas their unconditional counterparts are 
0.624 and 0.601 , and 0.71 , respectively. This again highlights the impreciseness of assuming static inter-sectoral correlations between domestic equities.

Appendix A depicts the evolution of the estimated DCCs between conditional volatility amongst each pair of employed sectors. In all cases, the DCC is positive. The heterogeneity in the dynamics of DCCs between the sector pairs is clear. In addition, sector pairs do not exhibit stable correlation pattern for a prolong period of time, implying that DCC estimates change in response to price increment shocks to each sector in the pair. Hence, using time-invariant estimates of co-movement can be misleading and is likely to yield incorrect inference and decisions regarding risk management and portfolio rebalancing.

Table 3. Testing for structural breaks in the estimated DCCs

\begin{tabular}{|c|c|c|c|c|c|c|c|c|}
\hline \multirow[t]{3}{*}{ DCC pairs } & \multirow[t]{3}{*}{ ADF test } & \multicolumn{5}{|c|}{ Mean Equation } & \multirow{2}{*}{\multicolumn{2}{|c|}{ Model Diagnostics }} \\
\hline & & \multicolumn{5}{|c|}{$\rho_{\mathrm{ij}, \mathrm{t}}=\rho_{0}+\rho_{\mathrm{ij}, \mathrm{t}-1}+\gamma_{k}$ Crisis $_{k, t}+e_{i j, t}$} & & \\
\hline & & $\rho_{0}$ & $\rho_{\mathrm{ij}, \mathrm{t}-1}$ & $\gamma_{1}$ & $\gamma_{2}$ & $\mathbf{R}^{2}$ & LB $Q_{(10)}$ & $\mathrm{LB}^{2} \mathrm{Q}_{(10)}$ \\
\hline BAN-CHM & $\begin{array}{c}\mathbf{- 6 . 6 5 5}(0) \\
{[0.000]}\end{array}$ & $\begin{array}{l}0.101 * \\
{[0.00]}\end{array}$ & $\begin{array}{c}0.813^{*} \\
{[0.00]}\end{array}$ & $\begin{array}{l}0.005 \\
{[0.51]}\end{array}$ & $\begin{array}{c}0.106 \\
{[0.12]} \\
\end{array}$ & 0.68 & $\begin{array}{c}6.46 \\
{[0.77]} \\
\end{array}$ & $\begin{array}{c}10 \\
{[0.44]}\end{array}$ \\
\hline BAN-COM & $\begin{array}{c}-\mathbf{- 3 . 0 8}(0) \\
{[0.02]}\end{array}$ & $\begin{array}{c}0.024^{*} \\
{[0.00]}\end{array}$ & $\begin{array}{l}0.95^{*} \\
{[0.00]}\end{array}$ & $\begin{array}{l}0.002 \\
{[0.46]}\end{array}$ & $\begin{array}{l}0.086 \\
{[0.13]}\end{array}$ & 0.92 & $\begin{array}{l}7.09 \\
{[0.71]} \\
\end{array}$ & $\begin{array}{l}5.3 \\
{[0.87]} \\
\end{array}$ \\
\hline BAN-FNS & $\begin{array}{c}\mathbf{- 9 . 3 7}(0) \\
{[0.000]}\end{array}$ & $\begin{array}{c}0.233^{*} \\
{[0.00]}\end{array}$ & $\begin{array}{l}0.67 * \\
{[0.00]}\end{array}$ & $\begin{array}{l}0.002 \\
{[0.78]}\end{array}$ & $\begin{array}{l}0.082 \\
{[0.12]}\end{array}$ & 0.47 & $\begin{array}{l}7.07 \\
{[0.71]}\end{array}$ & $\begin{array}{l}4.18 \\
{[0.93]}\end{array}$ \\
\hline BAN-ING & $\begin{array}{c}\mathbf{- 4 . 5 7}(0) \\
{[0.000]}\end{array}$ & $\begin{array}{c}0.06^{*} \\
{[0.00]} \\
\end{array}$ & $\begin{array}{l}0.91 * \\
{[0.00]}\end{array}$ & $\begin{array}{l}0.002 \\
{[0.51]}\end{array}$ & $\begin{array}{l}0.108 \\
{[0.12]}\end{array}$ & 0.82 & $\begin{array}{l}8.92 \\
{[0.53]} \\
\end{array}$ & $\begin{array}{l}12.09 \\
{[0.27]}\end{array}$ \\
\hline BAN-TEL & $\begin{array}{c}\mathbf{- 1 5 . 0 2}(0) \\
{[0.000]}\end{array}$ & $\begin{array}{c}0.411^{*} \\
{[0.00]}\end{array}$ & $\begin{array}{c}0.325^{*} \\
{[0.00]}\end{array}$ & $\begin{array}{l}-0.011 \\
{[0.47]}\end{array}$ & $\begin{array}{l}0.141 \\
{[0.11]}\end{array}$ & 0.35 & $\begin{array}{l}7.07 \\
{[0.71]}\end{array}$ & $\begin{array}{l}3.38 \\
{[0.97]}\end{array}$ \\
\hline CHM -COM & $\begin{array}{c}\mathbf{- 3 . 5 2}(0) \\
{[0.007]} \\
\end{array}$ & $\begin{array}{c}0.031^{*} \\
{[0.00]}\end{array}$ & $\begin{array}{c}0.943^{*} \\
{[0.00]}\end{array}$ & $\begin{array}{l}0.0001 \\
{[0.98]}\end{array}$ & $\begin{array}{l}0.100^{*} \\
{[0.01]} \\
\end{array}$ & 0.90 & $\begin{array}{l}9.62 \\
{[0.47]} \\
\end{array}$ & $\begin{array}{l}4.06 \\
{[0.94]} \\
\end{array}$ \\
\hline CHM-FNS & $\begin{array}{c}\mathbf{- 6 . 2 9}(0) \\
{[0.000]}\end{array}$ & $\begin{array}{c}0.119^{*} \\
{[0.00]}\end{array}$ & $\begin{array}{l}0.824^{*} \\
{[0.00]}\end{array}$ & $\begin{array}{l}0.007 * * * \\
{[0.10]}\end{array}$ & $\begin{array}{l}0.068^{* *} \\
{[0.05]}\end{array}$ & 0.71 & $\begin{array}{l}7.38 \\
{[0.68]}\end{array}$ & $\begin{array}{l}2.29 \\
{[0.99]}\end{array}$ \\
\hline CHM-ING & $\begin{array}{l}\mathbf{- 8 . 3}(0) \\
{[0.000]}\end{array}$ & $\begin{array}{c}0.214^{*} \\
{[0.00]}\end{array}$ & $\begin{array}{c}0.723^{*} \\
{[0.00]}\end{array}$ & $\begin{array}{l}0.007 * * * \\
{[0.06]}\end{array}$ & $\begin{array}{l}0.066^{* * * *} \\
{[0.06]}\end{array}$ & 0.55 & $\begin{array}{l}15.39 \\
{[0.11]}\end{array}$ & $\begin{array}{l}5.97 \\
{[0.81]}\end{array}$ \\
\hline CHM -TEL & $\begin{array}{c}\mathbf{- 4 . 8 7}(0) \\
{[0.000]} \\
\end{array}$ & $\begin{array}{c}0.063^{*} \\
{[0.00]} \\
\end{array}$ & $\begin{array}{l}0.896^{*} \\
{[0.00]}\end{array}$ & $\begin{array}{l}0.001 \\
{[0.75]} \\
\end{array}$ & $\begin{array}{l}0.085^{* *} \\
{[0.04]}\end{array}$ & 0.81 & $\begin{array}{l}5.87 \\
{[0.82]} \\
\end{array}$ & $\begin{array}{l}2.2 \\
{[0.99]}\end{array}$ \\
\hline COM-FNS & $\begin{array}{c}\mathbf{- 3 . 9}(0) \\
{[0.000]}\end{array}$ & $\begin{array}{c}0.023^{*} \\
{[0.00]}\end{array}$ & $\begin{array}{c}0.967^{*} \\
{[0.00]}\end{array}$ & $\begin{array}{l}0.0006 \\
{[0.74]}\end{array}$ & $\begin{array}{l}0.038^{* * * *} \\
{[0.09]}\end{array}$ & 0.94 & $\begin{array}{l}5.17 \\
{[0.80]}\end{array}$ & $\begin{array}{l}6.07 \\
{[0.81]}\end{array}$ \\
\hline COM-ING & $\begin{array}{c}\mathbf{- 3 . 1 9}(0) \\
{[0.021]}\end{array}$ & $\begin{array}{c}0.032^{*} \\
{[0.00]} \\
\end{array}$ & $\begin{array}{c}0.951^{*} \\
{[0.00]}\end{array}$ & $\begin{array}{l}0.001 \\
{[0.58]}\end{array}$ & $\begin{array}{l}0.063^{* * *} \\
{[0.08]}\end{array}$ & 0.92 & $\begin{array}{l}11.51 \\
{[0.31]}\end{array}$ & $\begin{array}{l}5.34 \\
{[0.86]} \\
\end{array}$ \\
\hline COM-TEL & $\begin{array}{c}\mathbf{- 8 . 7 8}(0) \\
{[0.000]}\end{array}$ & $\begin{array}{c}0.175^{*} \\
{[0.00]}\end{array}$ & $\begin{array}{c}0.697 * \\
{[0.00]}\end{array}$ & $\begin{array}{l}0.017 \\
{[0.13]}\end{array}$ & $\begin{array}{l}0.114^{*} \\
{[0.01]}\end{array}$ & 0.51 & $\begin{array}{l}10.83 \\
{[0.37]}\end{array}$ & $\begin{array}{l}3.49 \\
{[0.96]}\end{array}$ \\
\hline FNS-ING & $\begin{array}{c}\mathbf{- 8 . 3}(0) \\
{[0.000]}\end{array}$ & $\begin{array}{c}0.214^{*} \\
{[0.00]}\end{array}$ & $\begin{array}{c}0.723^{*} \\
{[0.00]}\end{array}$ & $\begin{array}{l}0.007 * * * \\
{[0.07]}\end{array}$ & $\begin{array}{l}0.066^{* * * *} \\
{[0.07]}\end{array}$ & 0.55 & $\begin{array}{l}15.39 \\
{[0.11]}\end{array}$ & $\begin{array}{l}5.97 \\
{[0.81]}\end{array}$ \\
\hline FNS-TEL & $\begin{array}{c}\mathbf{- 8 . 3 1}(0) \\
{[0.000]}\end{array}$ & $\begin{array}{l}0.219^{*} \\
{[0.00]}\end{array}$ & $\begin{array}{c}0.718^{*} \\
{[0.00]}\end{array}$ & $\begin{array}{l}-0.001 \\
{[0.96]}\end{array}$ & $\begin{array}{l}0.079^{*} \\
{[0.01]}\end{array}$ & - & $\begin{array}{l}4.51 \\
{[0.92]}\end{array}$ & $\begin{array}{l}7.68 \\
{[0.66]}\end{array}$ \\
\hline ING-TEL & $\begin{array}{c}\mathbf{- 1 0 . 5}(0) \\
{[0.000]} \\
\end{array}$ & $\begin{array}{c}0.298^{*} \\
{[0.00]} \\
\end{array}$ & $\begin{array}{c}0.575^{*} \\
{[0.00]}\end{array}$ & $\begin{array}{l}0.018 * * \\
{[0.04]}\end{array}$ & $\begin{array}{l}0.098 * * \\
{[0.04]}\end{array}$ & 0.38 & $\begin{array}{l}4.51 \\
{[0.92]} \\
\end{array}$ & $\begin{array}{l}7.68 \\
{[0.66]}\end{array}$ \\
\hline
\end{tabular}

Notes: $*, * *, * * *$ indicate significance at $1 \%$ (or less), $5 \%$ (or less), or $10 \%$ (or less), respectively.

\section{Source: Authors' calculations}

From Table 3 displays the results of testing for structural breaks in the estimated DCCs during the global financial crash and political turmoil in Egypt in 2011. ADF tests, including a constant, indicate that the null hypothesis should be rejected at $1 \%$ for all estimated DCCs. The number of lags used in the ADF procedure, shown next to the calculated test statistics in parentheses, is automatically selected by AIC and $p$-values are in square brackets beneath calculated test statistics. The AR(1) model is found sufficient to capture all the dynamics in the DCCs, with exception of the FNS-TEL pair, since the Box-Pierce portmanteau statistic for the first ten autocorrelations of standardised residuals and their squared counterparts (i.e. $\mathrm{LB} \mathrm{Q}_{(10)}$ and $\mathrm{LB}^{2} \mathrm{Q}_{(10)}$, respectively) are found to be free from serial correlation. Regarding the DCC for FNS-TEL pair, an AR(1)-ARCH(1) is found sufficient to capture the dynamics of its first two moments with the constant and $\mathrm{ARCH}$ term, equal 0.002 and 0.151 respectively being significant beyond $1 \%$ level of significance whereas none of the dummy variables in the variance equation is found significant at any conventional levels of significance. The political turbulence in 2011 significantly increased the level of the DCC for the FNS-TEL pair but not its variability since the coefficients of the two crisis events are found insignificant at any conventional level of significance. The coefficient of the global financial crash, $\gamma_{1}$, is found positively significant in four cases, namely; CHM-FNS, CHM-ING, FNS-ING, and ING-TEL pairs. The political instability has significantly increased the level of 
the DCCs in ten cases out of fifteen. It is worth mentioning that the coefficient of political turmoil, $\gamma_{2}$, was found insignificant in all the pairs of banking sector. The $\mathrm{R}^{2}$ is found high in many cases and it ranges between a minimum of 0.35 for the BAN-TEL pair and a maximum of 0.94 for the COM-FNS pair.

\subsection{Causality between Equity Sector Index Volatilities and EX Volatility}

We test the stationarity of conditional variance series using ADF test and we find that all series are stationary ${ }^{2}$. In Table 4, we present the results obtained from the bootstrap LR causality test applied to the full-sample to test for static causality between the levels of both EXVOL and SVOL. The optimal lag length is chosen based on AIC and the number of bootstrap replication is set to 2000. The null hypothesis that SVOL does not Granger-cause EXVOL is rejected for all sectors whereas the null that the EXVOL does not Granger-cause SVOL could not be rejected for Construction and Materials sector and Telecommunications sector.

Table 4. Full sample bootstrap Granger non-causality tests between EX volatility and sector volatility

\begin{tabular}{|c|c|c|c|c|c|}
\hline \multirow[t]{2}{*}{ Sector } & \multirow[t]{2}{*}{ Lag length } & \multicolumn{2}{|c|}{$\begin{array}{l}\text { Ho: }_{0:} \text { SVOL does } \\
\text { EXVOL }\end{array}$} & \multicolumn{2}{|c|}{$\mathrm{H}_{0:}$ EXVOL does not cause SVOL } \\
\hline & & LR statistic & Bootstrap p-value & LR statistic & Bootstrap p-value \\
\hline BAN & 5 & $62.666^{*}$ & 0.000 & $12.598 * *$ & 0.043 \\
\hline $\mathrm{CHM}$ & 5 & $43.757 *$ & 0.001 & $14.323 * *$ & 0.034 \\
\hline $\mathrm{COM}$ & 8 & 24.264* & 0.002 & 12.494 & 0.136 \\
\hline FNS & 5 & $53.864 *$ & 0.000 & $14.204 * *$ & 0.022 \\
\hline ING & 5 & 58.274* & $\mathbf{0 . 0 0 0}$ & $24.188 * *$ & $\mathbf{0 . 0 1 5}$ \\
\hline TEL & 5 & 34.138* & 0.002 & 6.995 & 0.205 \\
\hline
\end{tabular}

$*, * *$ reject the null hypothesis at $1 \%$ and $5 \%$, respectively.

\section{Source: Authors' calculations}

Table 5 shows the results of the parameter constancy tests that investigate the stability of the coefficients of the VAR model. The critical values of Sup-LR, Mean-LR, and Exp-LR statistics and their corresponding $p$-values are obtained using a bootstrap approximation to the null distribution, constructed by employing Monte Carlo simulation with 2000 samples generated from a VAR model with constant parameters. These stability tests require trimming at the ends of the sample. As recommended by Andrews (1993), 15\% from both ends are trimmed and tests are calculated for the fraction of the sample in [0.15. 0.85]. The Sup-LR, Mean-LR and Exp- LR tests do not exhibit standard asymptotic properties. Critical values and $p$-values of these tests obtained by means of the parametric bootstrap method are reported by Andrews (1993) and Andrews and Ploberger (1994). The Sup-LR test is the appropriate in testing whether there was a swift regime shift whereas Mean-LR and Exp-LR tests are both optimal for testing the gradual stability of the model over time and assume that parameters follow a Martingale process (Andrews \& Ploberger, 1994). In the EXVOL equations, the three tests soundly reject the null hypothesis of parameter stability, implying that the relation between SVOL and EXVOL has experienced structural breaks during the study period. For the SVOL equations, the three tests agree in rejecting the null hypothesis of parameter constancy except for the Telecommunications sector equation. Accordingly, there is clear evidence of parameter instability. Thus, we re-estimate each VAR model in Equation.11 using rolling window procedure for a time span of 150 and 200 weekly observations (corresponding to roughly 3 and 4 years, respectively) as mentioned earlier. The RB causality tests are conducted for each VAR model using the first 150 (200) observations and, then the sample is rolled one observation forward, eliminating the first observation, performing the RB causality testing for the new window and this procedure is repeated until the last observation. For each sub-sample, we compute the RB $p$-values of the modified $L R$-statistics that test the absence of Granger-causality from EXVOL to SVOL or vice-versa. We found that results are insensitive to the window size, so we report results based upon the window size of 200 observations in Appendix B.

Appendix B displays the rolling bootstrap $p$-values of the LR statistics estimated using the subsamples data of EXVOL and SVOL in panels A through F for Banks, Chemicals, Construction and Materials, Financial Services excluding Banks, Industrial Goods, Services and Automobiles, and Telecommunications, respectively. In each graph, the horizontal axis shows the final observation in each of the 200-week rolling windows. If the estimated $p$-value is found greater than $10 \%$ (the horizontal line of each graph), then the null hypothesis of the absence of causality could not be rejected. Appendix B shows bi-directional Granger-causality between EXVOL and SVOL for all sectors, with exception of Telecommunications sector where a unidirectional causality runs from SVOL to EXVOL, until the beginning of year 2011. Thus, bidirectional causality existed between the two financial markets in Egypt before the political instability emerged in 2011. Regarding the period extending from the year 2011 to the second half of 2014, the bootstrap $p$-values indicate that the null hypothesis that EXVOL does not Granger-cause SVOL has to be rejected for all sectors. On the other hand, the null that SVOL does not Granger-cause EXVOL could not be rejected for the same period. Then, no causality could be detected between these two financial markets in either direction for the rest of the 
study period.

Table 5. Parameter Stability test

\begin{tabular}{|c|c|c|c|c|}
\hline \multirow[t]{2}{*}{ Tests } & \multicolumn{2}{|c|}{$\begin{array}{c}\text { EXVOL equation } \\
\end{array}$} & \multicolumn{2}{|c|}{ SVOL equation } \\
\hline & Statistics & Bootstrap p-value & Statistics & $\begin{array}{c}\text { Bootstrap } \\
\text { p-value }\end{array}$ \\
\hline \multicolumn{5}{|c|}{ Banks sector } \\
\hline Sup LR & 7.183* & 0.003 & $6.002 *$ & 0.006 \\
\hline $\operatorname{Exp} L R$ & $2.163^{*}$ & 0.001 & $1.177 * *$ & 0.013 \\
\hline Mean LR & $3.410^{*}$ & 0.000 & $1.866 * *$ & 0.026 \\
\hline \multicolumn{5}{|c|}{ Chemicals } \\
\hline Sup LR & $5.642 * *$ & 0.014 & $14.405 *$ & 0.000 \\
\hline $\operatorname{Exp} L R$ & $1.410^{*}$ & 0.009 & $2.931 *$ & 0.001 \\
\hline Mean LR & $2.272 * *$ & 0.011 & $3.143^{*}$ & 0.003 \\
\hline \multicolumn{5}{|c|}{ Construction and Materials } \\
\hline Sup LR & $6.172 *$ & 0.008 & $17.271 *$ & 0.000 \\
\hline $\operatorname{Exp}$ LR & $1.864 *$ & 0.001 & $3.333 *$ & 0.000 \\
\hline Mean LR & $2.843 *$ & 0.002 & $2.441^{*}$ & 0.009 \\
\hline \multicolumn{5}{|c|}{ Financial services- excluding banks } \\
\hline Sup LR & $5.862 *$ & 0.009 & $6.953 *$ & 0.002 \\
\hline $\operatorname{Exp} \mathbf{L R}$ & $1.727 *$ & 0.003 & $1.051 * *$ & 0.019 \\
\hline Mean LR & $2.828 *$ & 0.003 & $1.680 * *$ & 0.041 \\
\hline \multicolumn{5}{|c|}{ Industrial goods, services, and automobiles } \\
\hline Sup LR & $7.067 * *$ & 0.011 & $17.208^{*}$ & 0.001 \\
\hline $\operatorname{Exp}$ LR & $2.286^{*}$ & 0.004 & $4.791 *$ & 0.001 \\
\hline Mean LR & $3.089 *$ & 0.005 & $4.790 *$ & 0.002 \\
\hline \multicolumn{5}{|c|}{ Telecommunications } \\
\hline Sup LR & $5.734 * *$ & 0.011 & 2.076 & 0.301 \\
\hline $\operatorname{Exp}$ LR & $1.534 *$ & 0.007 & 0.492 & 0.403 \\
\hline Mean LR & $2.612 *$ & 0.008 & 0.953 & 0.402 \\
\hline
\end{tabular}

Notes: $*, * *$ indicate that the null hypothesis of parameter stability has to be rejected at $1 \%$ or less and $5 \%$ or less, respectively.

\section{Source: Authors' calculation}

\section{Conclusion}

Employing weekly observations for Egypt, the current paper examined the information flows across equity sectors using DCC-MGARCH model and investigated the presence of time-varying causality between EXVOL and SVOL using the bootstrap Granger non-causality tests in a GARCH-VAR framework. Results obtained from GARCH $(1,1)$ applied in the first step of the DCC framework indicated that volatility persistence varies across sectors implying that the time required for shocks to decrease to one half of its original size is approximately $11,3,15,3,8$ and 2 weeks for BAN, CHM, COM, FNS, ING, and TEL sectors, implying that different sectors synthesize the impact of a shock at different speeds. Findings of the second step of the DCC framework revealed that all DCCs show significant variations over time and that the impact of short term co-movement on the DCCs is generally low compared to the coefficients that measure the impact of the lagged DCCs on the current DCCs. The sum of these two coefficients is found less than unity, suggesting that the DCC model is adequate at measuring time-varying conditional correlations, and that it displays mean reversion along a constant level. All estimated DCCs are found positive. Heterogeneous patterns of information flows among the sector pairs are detected. These conclusions highlight the invalidity of assuming static inter-sectoral correlations between domestic equities when constructing and periodically re-balancing portfolios. We found significant increase in DCCs for four and ten out of fifteen DCC pairs during the global financial crash and political instability in Egypt accompanying the $25^{\text {th }}$ of January revolution. These findings indicate that the global financial crash has not widely affect diversification opportunities in the EGX whereas the recent political turmoil in Egypt has. The RB based modified-LR statistics was applied onto the conditional variance series extracted from GARCH(1,1) model to test for volatility transmission between EXVOL and SVOL in a bivariate VAR framework. Full-sample results show that EXVOL Granger-cause SVOL for all employed indexes whereas the volatility of Construction and Materials and Telecommunications sectors is found not Granger cause EXVOL. However, the parameter stability tests indicate the existence of structural changes in the relationship, and therefore, we use the RB based modified-LR test with fixed-length rolling sub-samples to analyse the time-varying causal relation between EXVOL and SVOL. Results confirm that the casual relationship between SVOL and EXVOL varies across time. 
Bidirectional volatility transmission was detected before the political instability emerged in 2011 . Unidirectional causality running from EXVOL to SVOL was detected during 2011 to the second half of 2014. For the rest of the period, no volatility spillover existed in either direction. Thus, Policymakers should be aware that volatility transmission between the foreign currency and equity markets are time varying. International investors must take into consideration equity and currency volatility risks when rebalancing their portfolios. EXVOL is likely to encourage international investors to invest more in their domestic exchanges since it puts additional risk on holding foreign assets from a domestic (currency) investors' perspective. Additionally, firms which depend on foreign exchange, even domestic firms with minimal international activities, should consider these interlinks when they manage exposures to foreign contracts and exchange rate risk to stabilize their earnings.

\section{Acknowledgment}

Financial support of Plymouth Business School and the Egyptian Educational and Cultural Bureau in London is highly appreciated. We are thankful to the participants of the Plymouth Business School seminar held on $24^{\text {th }}$, May 2016 and the participants of the Africa Meeting of the Econometric Society held during $29^{\text {th }}$, June $-1^{\text {st }}$ July 2017 at Ecole Supérieure de Banque, Algeria for their invaluable comments. We are grateful to the editor and the anonymous referees for their valuable suggestions.

\section{References}

Ahmed, A. A. (2014). Evolving and relative efficiency of MENA exchanges: evidence from rolling joint variance ratio tests. Ensayos Revista de Economia, XXXIII(1), 91-126.

Ahmed, W. M. A. (2016). The dynamic linkage between sector indices: the case of Egyptian stock market. International Journal of Economics and Finance, 8(4), mayo, 23-38. https://doi.org/10.5539/ijef.v8n4p23

Ahmed, W. M. A. (2017). The impact of foreign equity flows on market volatility during politically tranquil and turbulent times: the Egyptian experience. Research in International Business and Finance, 40, 61-77. https://doi.org/10.1016/j.ribaf.2016.12.006

Andrews, D. W. K. (1993). Tests for parameter instability and structural change with unknown change point. Econometrica, 61(4), 821-85. https://doi.org/10.2307/2951764

Andrews, D. W. K., \& Ploberger, W. (1994). Optimal tests when a nuisance parameter is present only under the alternative. Econometrica, 62(6), 1383-1414. https://doi.org/10.2307/2951753

Baele, L., Pungulescu, C., \& Ter, H. J. (2007). Model uncertainty, financial market integration and the home bias puzzle. Journal of International Money and Finance, 26(4), 606-630. https://doi.org/10.1016/j.jimonfin.2007.03.007

Balcilar, M., \& Ozdemir, Z. A. (2013). The export-output growth nexus in Japan: a bootstrap rolling window approach. Empirical Economics, 44(2), 639-660. https://doi.org/10.1007/s00181-012-0562-8

Balcilar, M., Ozdemir, Z. A., \& Arslanturk, J. (2010). Economic growth and energy consumption causal nexus viewed through a bootstrap rolling window. Energy Economics, 32, 1398-1410. https://doi.org/10.1016/j.eneco.2010.05.015

Beltratti, A., \& Morana, C. (2006). Breaks and persistency: macroeconomic causes of stock market volatility. Journal of Econometrics, 131, 151-177. https://doi.org/10.1016/j.jeconom.2005.01.007

Bollerslev, T., \& Wooldridge, J. M. (1992). Quasi-maximum likelihood estimation and inference in dynamic models with time-varying covariances. Econometric Reviews, 11, 143-172. http://dx.doi.org/10.1080/07474939208800229

Branson, W. H. (1983). Macroeconomic determinants of real exchange risk, in R.J. Herring (ed.), Managing Foreign Exchange Risk, Cambridge University Press, Cambridge, MA.

Caporale, G. M., Hunter, J., \& Ali, F. M. (2014). On the linkages between stock prices and exchange rates: evidence from the banking crisis of 2007-2010. International Review of Financial Analysis, 33, 87-103. https://doi.org/10.1016/j.irfa.2013.12.005

Chinzara, Z. (2011). Macroeconomic uncertainty and conditional stock market volatility in South Africa. South African Journal of Economics, 79(1), 27-49. https://doi/10.1111/j.1813-6982.2011.01262.x

Choudhry, T. (2004). International transmission of stock returns and volatility. Emerging Markets Finance and Trade, 40(4), 33-52. Retrieved from http://www.jstor.org/stable/27750399

Dickey, D. A., \& Fuller, W. A. (1981). Likelihood ratio statistics for autoregressive time series with a unit root. Econometrica, 49(4), 1057-1072. https://doi.org/10.2307/1912517

Dimitrova, D. (2005). The relationship between exchange rates and stock prices: studied in a multivariate model. Issues in Political Economy, 14. http://org.elon.edu/ipe/Dimitrova\%20final.pdf 
Dornbusch, R., \& Fisher, S. (1980). Exchange rates and the current account. American Economic Review, 70(5), 960-71. Retrieved from http://www.jstor.org/stable/1805775

Engle, R. (2002). Dynamic conditional correlation: a simple class of multivariate generalized autoregressive conditional heteroskedasticity models. Journal of Business and Economic Statistics, 20(3), 339-350. https://doi.org/10.1198/073500102288618487

Engle, R. F. (1982). Autoregressive Conditional Heteroscedasticity with Estimates of the Variance of United Kingdom Inflation, Econometrica, 50(4), 987-1007. DOI:10.2307/1912773

Engle, R., \& Sheppard, K. (2001). Theoretical and empirical properties of dynamic conditional correlation multivariate GARCH. NBER Working Paper 8554, National Bureau of Economic Research. (DOI):10.3386/w8554

Ewing, B. T., Forbes, S. M., \& Payne, J. E. (2003). The effects of Macroeconomic Shocks on Sector-specific Returns. Applied Economics, 35(2), 201-207. https://doi.org/10.1080/0003684022000018222

Ferreira, M. A., \& Ferreira, M. A. (2006). The Importance of Industry and Country Effects in the EMU Equity Markets. European Financial Management, 12(3), 341-373. https://doi.org/10.1111/j.1354-7798.2006.00324.x

Fidora, M., Fratzcher, M., \& Thimann, C. (2007). Home bias in global bond and equity markets: the role of real exchange rate volatility. Journal of International Money and Finance, 26, 631-655. https://doi.org/10.1016/j.jimonfin.2007.03.002

Frankel, J. A. (1983). Monetary and portfolio balance models of exchange rate determination, in Bhandari, J. S., \& Putnam, B. H. (eds), "Economic interdependence and flexible exchange rates". Cambridge, MA: MIT Press.

Fu, T. Y., Holmes, M. J., \& Daniel, F. S. C. (2011). Volatility transmission and asymmetric linkages between the stock and foreign exchange markets: a sectoral analysis. Studies in Economics and Finance, 28(1), 36-50. https://doi.org/10.1108/10867371111110543

Goetzmann, W., Li, L., \& Rouwenhorst, G. (2005). Long-term global market correlations, Journal of Business, 78, 1-38. https://doi.org/10.1086/426518

Hansen, B. E. (1990). Lagrange multiplier for parameter instability in non-linear models. Mimeo. Department of Economics, University of Rochester.

Hassan, S. A., \& Malik, F. (2007). Multivariate GARCH modelling of sector volatility transmission. The Quarterly Review of Economics and Finance, 47(3), 470-480. https://doi.org/10.1016/j.qref.2006.05.006

Hatemi, J. A., \& Roca, E. (2006). A re-examination of international portfolio diversification based on evidence from leveraged bootstrap methods. Economic Modeling, 23, 993-1007. https://doi.org/10.1016/j.econmod.2006.04.009

Jayasinghe, P., \& Tsui, A. K. (2008). Exchange rate exposure of sectoral returns and volatilities: evidence from Japanese industrial sectors. Japan and the World Economy, 20(4), 639-60. https://doi.org/10.1016/j.japwor.2007.07.003

Kanas, A. (2000). Volatility spillovers between stock returns and exchange rate changes: International Evidence. Journal of Business Finance \& Accounting, 27, 447-467. https://doi.org/10.1111/1468-5957.00320

Katzke, N. (2013). South African sector return correlations: using DCC and ADCC multivariate GARCH techniques to uncover the underlying dynamics. Working Paper No.17/13. Department of Economics, University of Stellenbosch.

Koutmos, G., \& Knif, J. (2003). Exchange rate exposure: evidence from Finnish stock returns', EFMA 2003 Helsinki Meetings. https://doi.org/10.2139/ssrn.407845

Koutmos, G., \& Marti, A. (2003). First and second moments exchange rate exposure: evidence from US stock returns. The Financial Review, 38(3), 455-71. https://doi.org/10.1111/1540-6288.00055

Kumar, M. (2013). Returns and volatility spillover between stock prices and exchange rates: empirical evidence from IBSA countries. International Journal of Emerging Markets, 8(2), 108-128. https://doi.org/10.1108/17468801311306984

Kumari, J., \& Mahakud, J. (2015). Relationship between conditional volatility of domestic macroeconomic factors and conditional stock market volatility: some further evidence from India. Asia-Pacific financial markets, 22(1), 87-111. https://doi.org/10.1007/s10690-014-9194-7

Mollah, S., Zafirov, G., \& Quoreshi, A. S. (2014). Financial Market Contagion during the Global Financial Crisis. Working Paper Series No.2014/5, Centre for Innovation and Technology Research, Sweden.

Morales, L. (2008). Volatility spillovers between stock returns and foreign exchange rates: evidence from four Eastern European countries. the Financial Management Association (FMA) European Conference, Prague, Czech Republic, 
4-6 June.

Morelli, D. (2002). The relation between conditional stock market volatility and conditional macroeconomic volatility: empirical evidence based on UK data. International Review of Financial Analysis, 11, 101-110. https://doi.org/10.1016/S1057-5219(01)00066-7

Muñoz, M. P., Marquez, M. D., \& Sánchez, J. A. (2011). Contagion between United States and European markets during the Recent Crises. AESTIMATIO, the IEB International Journal of Finance, 2, 2-25. https://mpra.ub.uni-muenchen.de/35993/

Ngene, G., \& Gordon, J. W. (2015). Sector volatility shift modelling, persistence and dynamic information flows. South West Finance Association Conference, 12-14 March, Houston.

Nyblom, J. (1989). Testing for the constancy of parameters over time. Journal of the American Statistical Association, 84(405), 223-230. https://doi.org/10.1080/01621459.1989.10478759

Phylaktis, K., \& Xia, L. (2006). Sources of Firms' Industry and Country Effects in Emerging Markets. Journal of International Money and Finance, 25, 459- 475. https://doi.org/10.1016/j.jimonfin.2006.02.001

Stock, J. H., \& Watson, M. W. (2002). Has the Business Cycle Changed and Why? NBER Macroeconomic Annual 59-218. doi/abs/10.1086/ma.17.3585284

Su, C. W., Yu, H., Chang, H. L., \& Li, X. L. (2016). How does inflation determine inflation uncertainty? A Chinese Perspective, Quality \& Quantity, 1-18. https://doi.org/10.1007/s11135-016-0341-2

Tamakoshi, G., \& Hamori, S. (2014). Spillovers among CDS indexes in the US financial Sector. North American Journal of Economics and Finance, 27, 104-113. https://doi.org/10.1016/j.najef.2013.12.001

Tamakoshi, G., \& Hamori, S. (2016). Time-varying co-movements and volatility spillovers among financial sector CDS indexes in the UK. Research in International Business and Finance, 36, 288-296. https://doi.org/10.1016/j.ribaf.2015.09.027

Website of the EGX: http://www.egx.com.eg/english/homepage.aspx

\section{Notes:}

Note 1. Results are not reported to save space; however, they are available upon request.

Note 2. Results of ADF test are not reported to save space. They are available upon request. 


\section{Appendix A}

Dynamic Conditional Correlation between Equity Returns of Employed Sector Indexes

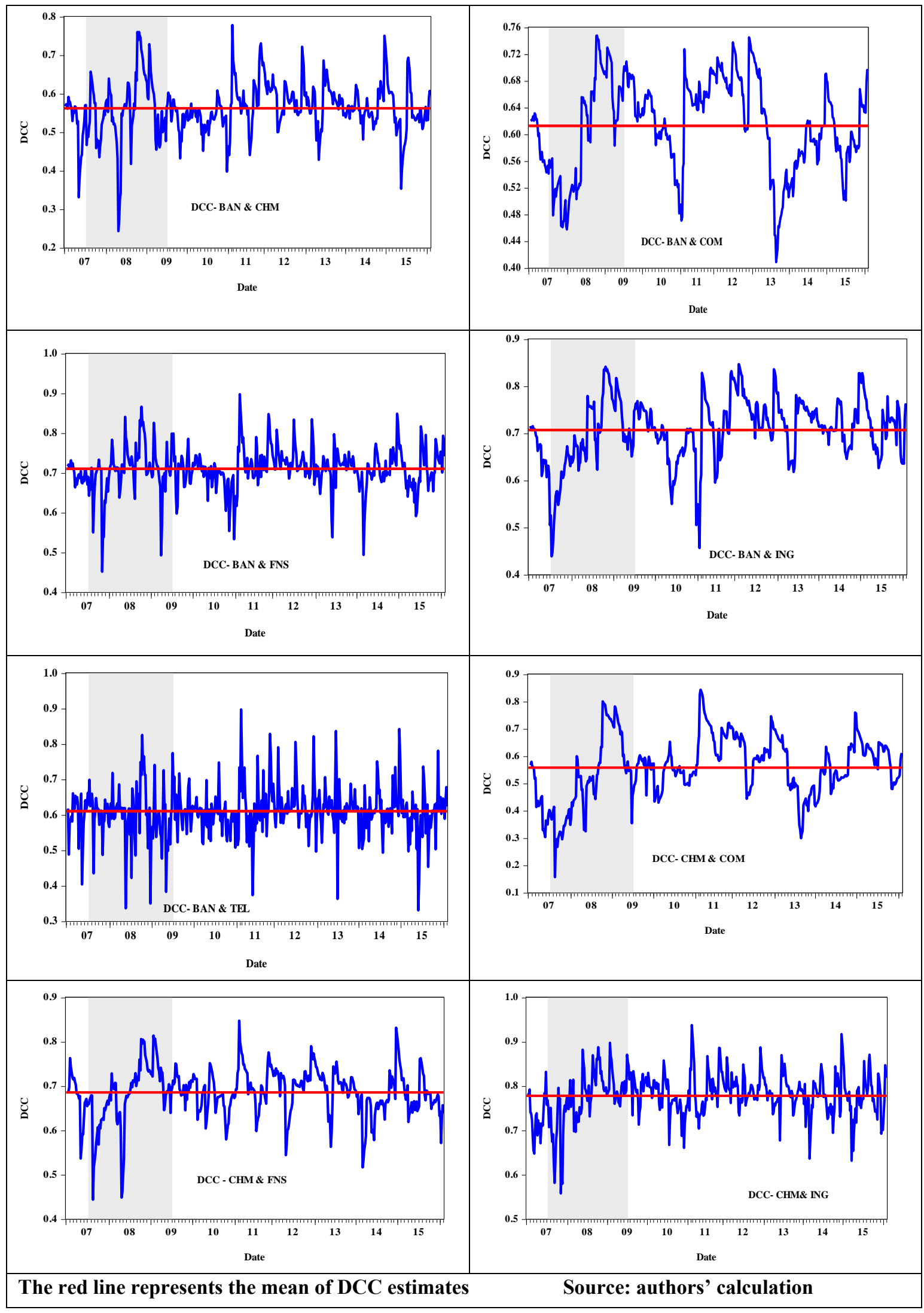




\section{Appendix A: Continued}

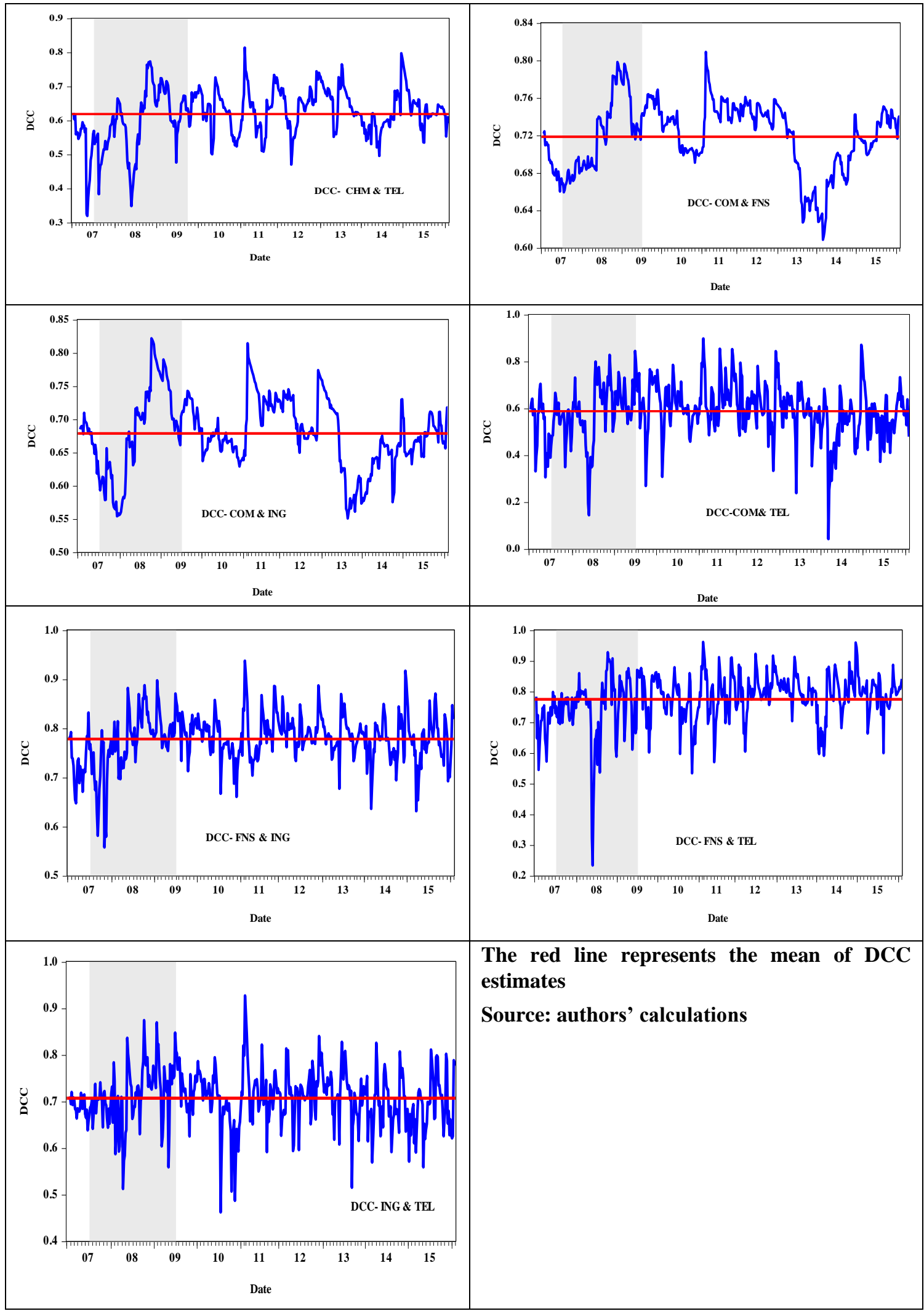




\section{Appendix B}

Dynamic Causality between Employed Equity Sectors and EX Volatility

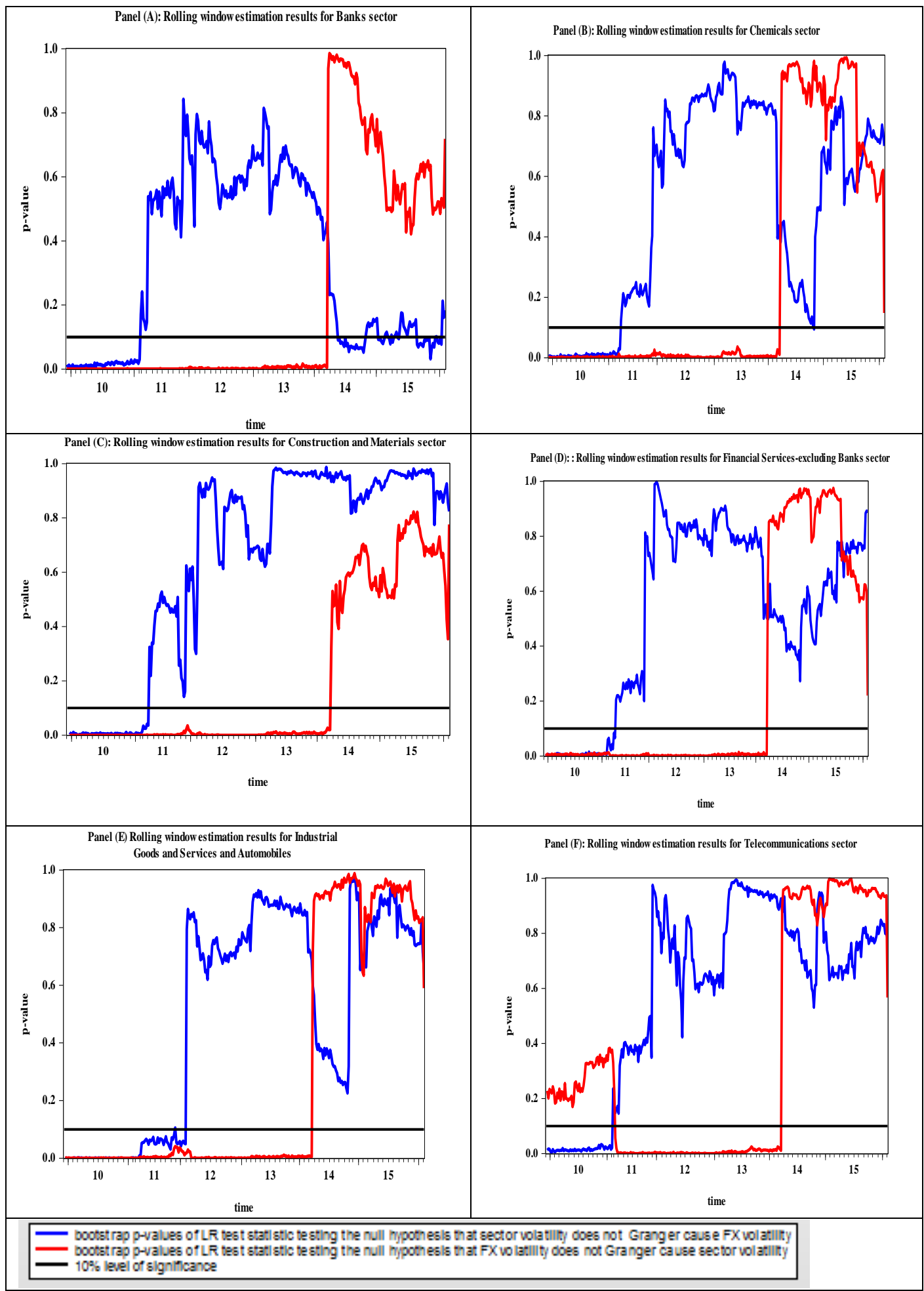

\section{Copyrights}

Copyright for this article is retained by the author(s), with first publication rights granted to the journal.

This is an open-access article distributed under the terms and conditions of the Creative Commons Attribution license which permits unrestricted use, distribution, and reproduction in any medium, provided the original work is properly cited. 